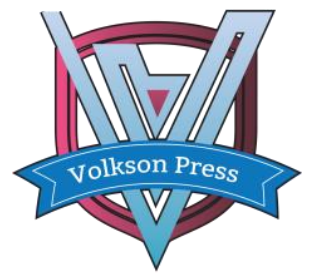

Contents List available at VOLKSON PRESS

Economics \& Management Innovations(EMI)

DOI : http://doi.org/10.26480/icemi.01.2017.204.205

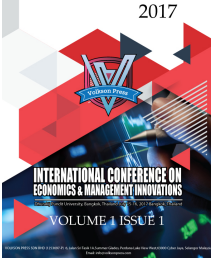

\title{
Factors Atfecting the Purchase Intention of Luxury Products: A Study of Chinese Tourists in Thailand
}

\author{
Yuanjing Xue \\ 580/108 Life@Ratchada Condo, Chan Kasem, Chatuchak, Bangkok, Thailand \\ kattie.xue0110@gmail.com \\ This is an open access article distributed under the Creative Commons Attribution License, which permits unrestricted use, distribution, and reproduction in any \\ medium, provided the original work is properly cited.
}

\section{ARTICLE DETAILS}

\section{Article History:}

Received 02 october 2017

Accepted 06 october 2017

Available online 11 october 2017

Keywords:

Purchase Intention, Consumer

Luxury, Chinese Tourists,

Thailand

\section{ABSTRACT}

Objective - This research is to study the purchase intention of Chinese tourists in Bangkok on the luxury perspective. So that the luxury manufacturers can realign their strategies to meet this geographical marketing shift, and their service offering to the buying behaviors of the consumer. Methods - In this research, quantitative method is applied. The Pearson Correlation Coefficient is used to evaluate the relationship between independent variables and purchase intention. Results - the price difference factors between Thailand and China were the most significant variables that influence the Chinese tourists to purchase luxury goods in Thailand.

Conclusion - the luxury purchase intention of Chinese tourists in Thailand is influenced by social value, functional value, personal value and tourism perceptions.

\section{Introduction}

Traditionally, luxury goods have been defined as goods for use or display that brings prestige to the owner, apart from any functional values (Grossman and Sharpiro, 1988). Thailand is the largest market of Southeast Asia for luxury goods (Luxurydaily, 2015). The sales are contributed by both Thai consumers and tourists. Among the tourists, Chinese tourism is the most important part (Bangkok Post, 2016). This paper aims to study the purchase intention of Chinese tourists in Thailand. So that the luxury manufacturers can realign their strategies to meet this geographical marketing shift and the buying behaviors of the consumer.

\section{Literature Review}

Luxury consumption consists of two main categories of reasons for luxury goods consumption: the external motivations and internal motivations. Firstly, luxury products are consumed to satisfy social positioning and status. In the second case, consumption involves more personal value. Consumers are affected by the internal factors. They tend to purchase luxury goods to create a self-image (Guido, 2011)

Under the development of tourism industry, tourism retailing is a fastgrowing business with potentials. Toporowski (2015) propose that tourist shopping intention is influenced by impulsive purchase behavior, and experiential perceptions. Shukla (2012) identified that luxury consumption is influenced by three perspectives: Social value perception (conspicuousness and status values); Personal value perception (hedonism and materialism values); Functional value perception (uniqueness values and price-quality values). On the other hand, Meng and $\mathrm{Xu}(2012)$ proposed that when tourism shopping behavior is an impulsive behavior, it is influenced by: Product factors, personal factors and situation factors. Moreover, tourism shopping behavior is influenced by experiential factors as well.

The conceptual framework of this research is based on the previous study of Shukla (2012) and Meng and Xu (2012). However, according to the differentiation of the luxury price between China and Thailand market, the price factor in tourism context is also considerate in this study. Therefore, the conceptual framework of this study is proposed in Fig. 1.

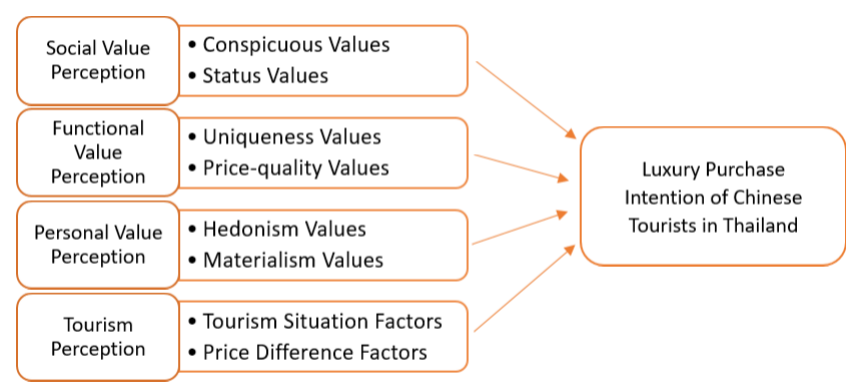

Figure 1. The conceptual framework

$\mathrm{H} 1_{0}$ : Conspicuous values do not significantly influence luxury purchase intention of Chinese tourists in Thailand.

H20: Status values do not significantly influence luxury purchase intention of Chinese tourists in Thailand.

H30: Uniqueness values do not significantly influence luxury purchase intention of Chinese tourists in Thailand.

H40: Price-quality values do not significantly influence luxury purchase intention of Chinese tourists in Thailand.

H50: Hedonism Values do not significantly influence luxury purchase intention of Chinese tourists in Thailand.

H60: Materialism values do not significantly influence luxury purchase intention of Chinese tourists in Thailand.

H70: Tourism situation factors do not significantly influence luxury purchase intention of Chinese tourists in Thailand.

H80: Price difference factors do not significantly influence luxury purchase intention of Chinese tourists in Thailand.

\section{Research Methodology}

In this research, quantitative method is applied. The data collection was conducted on Chinese social online media. The respondents of the study 
are the Chinese tourists in Thailand and has been to Thailand for tourism propose, and have purchase intention of luxury products. The respondents sample size of this research is 205 respondents. The Pearson Correlation Coefficient is used to evaluate the relationship between independent variables and purchase intention. Table 1 summarized the results:

Table 1 Summarized the results:

\begin{tabular}{|c|c|c|}
\hline $\begin{array}{l}\text { Independent } \\
\text { Variables }\end{array}$ & Hypothesis & Results \\
\hline $\begin{array}{l}\text { Conspicuous } \\
\text { Values }\end{array}$ & $\begin{array}{l}\text { H10: Conspicuous values do not } \\
\text { significantly influence luxury } \\
\text { purchase intention of Chinese } \\
\text { tourists in Thailand. }\end{array}$ & $\begin{array}{l}\text { Rejected } \\
\left(\mathrm{r}=.254^{* *}\right)\end{array}$ \\
\hline Status Values & $\begin{array}{l}\text { H20: Status values do not } \\
\text { significantly influence luxury } \\
\text { purchase intention of Chinese } \\
\text { tourists in Thailand. }\end{array}$ & $\begin{array}{l}\text { Rejected } \\
\left(\mathrm{r}=.207^{* *}\right)\end{array}$ \\
\hline $\begin{array}{l}\text { Uniqueness } \\
\text { Value }\end{array}$ & $\begin{array}{l}\text { H30: Uniqueness values do not } \\
\text { significantly influence luxury } \\
\text { purchase intention of Chinese } \\
\text { tourists in Thailand. }\end{array}$ & $\begin{array}{l}\text { Rejected } \\
\left(\mathrm{r}=.241^{* *}\right)\end{array}$ \\
\hline $\begin{array}{l}\text { Price-quality } \\
\text { Value }\end{array}$ & $\begin{array}{l}\text { H40: Price-quality values do not } \\
\text { significantly influence luxury } \\
\text { purchase intention of Chinese } \\
\text { tourists in Thailand. }\end{array}$ & $\begin{array}{l}\text { Rejected } \\
\left(\mathrm{r}=.148^{*}\right)\end{array}$ \\
\hline $\begin{array}{l}\text { Hedonism } \\
\text { Value }\end{array}$ & $\begin{array}{l}\text { H50: Hedonism Values do not } \\
\text { significantly influence luxury } \\
\text { purchase intention of Chinese } \\
\text { tourists in Thailand. }\end{array}$ & $\begin{array}{l}\text { Rejected } \\
\left(\mathrm{r}=.321^{* *}\right)\end{array}$ \\
\hline $\begin{array}{l}\text { Materialism } \\
\text { Values }\end{array}$ & $\begin{array}{l}\text { H60: Materialism values do not } \\
\text { significantly influence luxury } \\
\text { purchase intention of Chinese } \\
\text { tourists in Thailand. }\end{array}$ & $\begin{array}{l}\text { Rejected } \\
\left(\mathrm{r}=.169^{*}\right)\end{array}$ \\
\hline & Table 1.Con & \\
\hline $\begin{array}{l}\text { Tourism } \\
\text { Situation } \\
\text { Factors }\end{array}$ & $\begin{array}{l}\text { H70: Tourism situation factors do } \\
\text { not significantly influence luxury } \\
\text { purchase intention of Chinese } \\
\text { tourists in Thailand. }\end{array}$ & $\begin{array}{l}\text { Rejected } \\
\left(\mathrm{r}=.146^{*}\right)\end{array}$ \\
\hline $\begin{array}{l}\text { Price Difference } \\
\text { Factors }\end{array}$ & $\begin{array}{l}\text { H80: Price difference factors do not } \\
\text { significantly influence luxury } \\
\text { purchase intention of Chinese } \\
\text { tourists in Thailand. }\end{array}$ & $\begin{array}{l}\text { Rejected } \\
\left(\mathrm{r}=.371^{* *}\right)\end{array}$ \\
\hline
\end{tabular}

\section{Conclusion}

To conclude, the luxury purchase intention of Chinese tourists in Thailand is influenced by social value, functional value, personal value and tourism perceptions. Among all the factors, the price difference factors between Thailand and China were the most significant variables that influence the Chinese tourists to purchase luxury goods in Thailand. Therefore, the decreasing of the price will be attractive for Chinese tourists to make purchase in Thailand. On the other hand, the hedonism values also proved to be important for Chinese tourists. Therefore, the luxury producers may consider adding hedonism factors during shopping process.

\section{References}

[1] Grossman, G.M. and Sharpiro, C. (1988, March), Counterfeit-product trade, The American Economic Review, pp. 59-75.

[2] Luxurydaily. (2015), "4 Hot Markets for International Luxury Ecommerce", retrieved from http://www.luxurydaily.com/4-hotmarkets-for-international-luxury-ecommerce/.

[3] Bangkok Post. (2015), Chinese tourism to grow 16\% annually in Thailand, retrieved

from

http://www.bangkokpost.com/business/tourism-and-

transport/832528/chinese-tourism-to-grow-16-annually-in-thailand

[4] Guido, G. (2011),"Determinants of purchasing intention for fashion luxury goods in the Italian market", Journal of Fashion Marketing and Management: An International Journal, Vol. 15 Iss 1 pp. 123 - 136

[5] Toporowski, A.W.S.Z.W. (2015), "Shopping Travel Behavior", International Journal of Retail \& Distribution Management, Vol. 43, pp. 469 -484 .

[6] Meng, F. and Xu, Y. J. (2012), “Tourism shopping behavior: planned, impulsive, or experiential?", International Journal of Culture, Tourism and Hospitality Research, Vol. 6. pp. $250-265$.

[7] Shukla, P. (2012), "The influence of value perceptions on luxury purchase intentions in developed and emerging markets", International Marketing Review, Vol. 29. pp. 574 - 596. 